\title{
APLICAÇÃO DO DIREITO DO CONSUMIDOR NAS INCORPORAÇÕES IMOBILIÁRIAS
}

\author{
APPLICATION OF CONSUMER LAW IN REAL ESTATE DEVELOPMENTS
}

\author{
Alexis Mendonça Cavichini Teixeira de Siqueira ${ }^{1}$
}

Silvia Renata de Oliveira Penchel ${ }^{2}$

\begin{abstract}
Resumo: Esta pesquisa tem como objetivo abordar a forma como se dá a aplicação do direito do consumidor no caso de vendas de unidades autônomas em incorporações imobiliárias no Brasil. O método utilizado para a confecção do trabalho é o dedutivo, pois parte de premissas para poder se elaborar uma conclusão e um raciocínio lógico final a respeito das perspectivas e problemática atual do tema no direito pátrio. É verificado em qual âmbito se aplicam o código de defesa do consumidor no Brasil para essas relações e em qual âmbito sua aplicação é afastada, seja para a aplicação de legislação especial ou do próprio código civil. A pesquisa trata ainda da aplicação do diálogo das fontes normativas a essas relações de compra e venda de imóveis quando envolvem empreendimentos imobiliários e a inaplicabilidade da legislação consumerista, uma vez que não há disciplina específica a essas relações em uma só fonte normativa. Ao fim, conclui-se que a proteção do consumidor no ordenamento brasileiro é suficiente no âmbito das incorporações imobiliárias.
\end{abstract}

Palavras-chave: Direito do Consumidor; Incorporações imobiliárias; Legislação imobiliária.

\begin{abstract}
This research aims to address the way in which consumer law is applied in the case of sales of autonomous units in real estate developments in Brazil. The method used for making the work is the deductive one, since it starts from premises to be able to elaborate a conclusion and a final logical reasoning regarding the perspectives and current problems of the theme in Brazilian law. It is verified in which scope the consumer protection code in Brazil is applied for these relations and in which scope its application is removed, either for the application of special legislation or of the civil code itself. The research also deals with the application of the dialogue of the normative sources to these relations of purchase and sale of real estate when they involve real estate projects and the inapplicability of consumerist legislation, since there is no specific discipline to these relations in a single normative source. In the end, it is concluded that the consumer protection in the brazilian legal system is suficiente in the real estate developments.
\end{abstract}

Keywords: Consumer law; Real estate developments; Real estate legislation.

\section{Introdução}

O direito do consumidor, também chamado de direito do consumo, é um ramo do direito que ganhou em importância e autonomia a partir da segunda metade do século

\footnotetext{
${ }^{1}$ Mestre em ciências jurídico políticas pela - Universidade Portucalense - UPT/Portugal; Doutor em Direito pela UCSF/Argentina, Oficial do $4^{\circ}$ Registro de Imóveis do Rio de Janeiro.

E-mail: alexismcs@yahoo.com

${ }^{2}$ Pós-Graduada em Direito Notarial e Registral, Tabeliã e Oficial do Ofício único de Quatis/RJ.

E-mail: silviapenchel@hotmail.com
} 
XX, e chega ao século XXI abarcando diversas relações jurídicas que tradicionalmente ficavam a cargo do direito civil.

Ocorre que o direito civil não desapareceu completamente. Ele continua aplicável à diversas relações jurídicas, e aplicável a relações regidas pela legislação consumerista, normalmente de forma subsidiária.

Saber quando aplicar o código de defesa do consumidor no Brasil, leis específicas que tratam de incorporações imobiliárias ou quando aplicar as normas de direito civil é tema complexo.

O tema fica ainda mais complexo no tocante às incorporações imobiliárias, ou seja, empreendimentos imobiliários cujos proprietários pretendam vender os imóveis ainda em construção, ou, como se diz no jargão popular, "na planta".

Essa complexidade ocorre porque a legislação envolvida é a imobiliária. A legislação imobiliária possui peculiaridades que muitas vezes não se aplicam (nem teriam como se aplicar) ao direito do consumidor, muito pensado em regular relações de consumo de bens móveis de pequeno valor ou serviços prestados em massa. A compra e venda de imóveis, especialmente em construção é uma relação jurídica que envolve todo um feixe de relações, entre o adquirente, o construtor, o incorporador e os demais adquirentes.

Desta maneira, o presente trabalho tem por objetivo analisar o âmbito de aplicação da legislação consumerista em incorporações imobiliárias no Brasil. Onde a legislação consumerista não seja aplicável, será analisada a legislação pertinente, em especial o código civil, que possuem extensa regulamentação sobre contratos e sobre direitos reais.

A hipótese aqui trabalhada é que a legislação é suficiente para a proteção do adquirente de imóveis em construção, especificamente no âmbito das incorporações imobiliárias. Ao fim, espera-se concluir se a legislação brasileira é suficiente, insuficiente ou se foi muito adiante na proteção do consumidor e acabou por desequilibrar as relações jurídicas de consumo, gerando ônus excessivo ao empreendedor.

\section{Incorporações imobiliárias e o código de defesa do consumidor}

O contrato, conforme definição clássica, deve ser cumprindo, de acordo com a máxima latina pacta sunt servanda, ou seja, o pactuado deve ser observado pelos contratantes. A 
obrigatoriedade do contrato é base do direito contratual. ${ }^{3}$ Poucos iriam se aventurar em fazer um contrato sabendo que o mesmo poderia ser ou não cumprido de acordo com o bel-prazer da outra parte.

Desta maneira, ainda no entendimento tradicional do direito contratual, sobreleva-se o princípio da autonomia da vontade. Esse princípio "Significa o poder dos indivíduos de suscitar, mediante declaração de vontade, efeitos reconhecidos e tutelados pela ordem jurídica. No exercício desse poder, toda pessoa capaz tem aptidão para provocar o nascimento de um direito, ou para obrigar-se." 4

Ocorre que modernamente tem havido cada vez mais uma intervenção governamental no direito de contratar, em uma verdadeira tutela do direito contratual. Além disso, novos princípios ganham força, como o da função social do contrato ${ }^{5}$ e a boa-fé objetiva. ${ }^{6}$ Tais princípios acabam por relativizar a força obrigatória do contrato e seu alcance restrito entre as partes.

A ideia da função social do contrato e a flexibilização do princípio da força obrigatória do contrato não é tão novo quanto parece. Sua aplicação pode até ser. Porém, no início do século XX, o grande jurista alemão Gustav Radbruch já lamentava o caráter por demais "liberal" do BGB, o código civil alemão, que segundo ele, deveria ter mais atenção ao pensamento social. ${ }^{7}$

Essa intervenção governamental efetuada tem por objetivo equilibrar o contrato, e deixar o mesmo mais "justo", uma vez que o entendimento predominante, no atual estado de bem-estar social, é que existiria um desnível econômico entre os contratantes, de maneira que se faria necessária uma intervenção governamental no âmbito do direito contratual para reequilibrar o mesmo. Ocorre que "Nem sempre o Estado mostrou-se bem-sucedido na tarefa. A excessiva intervenção na ordem econômica privada ocasiona distorções a longo prazo". ${ }^{8}$

A tendência observada, desde o fim da primeira guerra mundial, com as primeiras constituições sociais, é de se aumentar sempre o escopo do Estado nas relações privadas. Primeiramente, com a legislação trabalhista, posteriormente com a intervenção nos contratos que tinham um viés "social" como o de locação, e, finalmente, chegando as relações de

\footnotetext{
${ }^{3}$ VENOSA, Silvio de Salvo. Direito civil: Teoria Geral das obrigações e Teoria geral dos contratos. (4 ${ }^{\mathrm{a}}$ ed) São Paulo: Atlas, 2004, p. 390.

${ }^{4}$ GOMES, Orlando. Contratos. (16 ed). Rio de Janeiro: Forense, 1995, p. 22.

${ }^{5}$ TEPEDINO, Gustavo; BARBOZA, Heloisa Helena; BODIN DE MORAES, Maria Celina de. Código civil interpretado - Conforme a Constituição da República, Vol. II. (2 ${ }^{\mathrm{a}}$ ed). Rio de Janeiro: Renovar, 2012, p. 12.

${ }^{6}$ Ibidem, p. 16.

${ }^{7}$ RADBRUCH, Gustav. Introdução à ciência do direito. (2a ed). São Paulo: Martins Fontes, 2010, p. 77.

${ }^{8}$ VENOSA, Silvio de Salvo. Direito civil: Teoria Geral das obrigações e Teoria geral dos contratos. (4 ed) São Paulo: Atlas, 2004, p. 391.
} 
consumo. Hoje o Estado conclama uma ainda maior participação na vida particular dos indivíduos, em uma tendência (ainda) de crescimento. ${ }^{9}$

Chegamos, então, ao atual estágio da evolução da situação contratual no Brasil, bem como em diversos outros países. Hoje temos uma situação de grande intervenção e tutela governamental nas relações privadas, caracterizada em grande parte no Brasil pelo código de defesa do consumidor, que abrange todas as relações ditas "de consumo". Assim, em cada contrato, devemos efetuar um diálogo das fontes normativas, para aplicar o código civil ou o código de defesa do consumidor, conforme a relação analisada.

O código de defesa do consumidor foi instituído por meio da lei 8.078/1990 que trouxe uma caracterização bastante alargada de sua aplicação, conforme depreende-se da leitura de seus artigos $2^{\circ}$ e $3^{\circ}$, quando da definição de consumidor e de fornecedor, respectivamente, para fins legais. ${ }^{10}$

Desta maneira, a incorporação de bens imóveis pode ser considerada uma atividade enquadrada dentro do âmbito do código de defesa do consumidor, quando o comprador não é um profissional, como seria o caso de um investidor. O incorporador, ao comercializar unidades em construção ou a serem construídas se encaixa perfeitamente na definição de fornecedor do artigo $3^{\circ}$ do citado código.

No entanto, a lei específica que rege as incorporações imobiliárias, lei 4.591/64, já possui diversas normativas protetivas ao consumidor, muitas vezes adiantando os princípios vistos na lei 8.078/1990, em especial em relação a publicidade. Desta maneira, a aplicação do código de defesa do consumidor em incorporações imobiliárias deve ser visto com cuidado e sempre levando-se em conta a lei específica de regência das incorporações. ${ }^{11}$ Não obstante essas leis, próprio o código civil ainda continua aplicável em diversas relações referentes a incorporação.

Importante ter-se em vista que o código de defesa do consumidor, em uma simples leitura do mesmo, deixa resplandecer que foi pensado tendo em vista a tutela contratos de compra e venda de bens móveis de pequeno valor ou a prestação de serviços do dia-a-dia.

A incorporação imobiliária é um contrato extremamente complexo, que leva em conta e afeta diversas pessoas além dos contratantes. Dessa maneira, a sua tutela jurídica deve ser efetuada levando-se em conta as características próprias e a legislação específica, que não foi revogada pelo código consumerista.

\footnotetext{
${ }^{9}$ A respeito da crescente intervenção do Estado nas relações privadas desde o início do Sec. XX, Vide: HOPPE, Hans Herman. Democracia: O Deus que falhou. São Paulo: Instituto Ludwig Von Mises Brasil, 2014.

${ }^{10}$ BRASIL. Código de defesa do consumidor, lei 8.078, de 11 de setembro de 1990.

${ }^{11}$ CHALHUB, Melhim Namem. Incorporação imobiliária. (4a ed.) Rio de Janeiro: Forense, 2017, p. 335.
} 
1.1 Lei de incorporações imobiliárias e código de defesa do consumidor - Proteção complementar ao adquirente

A lei de incorporações imobiliárias, lei 4.591/64, antecipando-se ao código de defesa do consumidor, trouxe em seu bojo extensa regulamentação de caráter protetivo do adquirente de imóveis em fase de construção ou a construir. Essa lei se fez necessária exatamente porque à época de sua promulgação a ocorria cada vez mais situações que deixavam o comprador desamparado, uma vez que as normativas existentes não eram suficientes. ${ }^{12}$

A partir da vigência da lei de incorporações imobiliárias, o incorporador passou a ter diversas obrigações frente ao comprador. Devemos observar que as obrigações postas por essa lei se aplicam tanto para o adquirente consumidor quando para o investidor. Não havia, à época, a diferenciação feita pela lei das categorias, uma vez que tudo era tratado de forma genérica pela legislação civilista.

Entre as exigências legais ao incorporador, temos a necessidade de prestação de informações de forma clara ao consumidor. Essa prestação de informações de materializa tanto no arquivamento do memorial de incorporação imobiliária junto ao cartório de registro de imóveis competente ${ }^{13}$, cujos documentos poderão ser consultados por qualquer interessado, dada a natureza pública deles, como também na obrigação do incorporador em deixar seu nome expresso em qualquer proposta de venda do empreendimento ${ }^{14}$, ou ainda a obrigação de informação quanto ao estado da obra. ${ }^{15}$

O código de defesa do consumidor foi promulgado apenas 26 anos após a lei de incorporações imobiliárias. O código elenca entre os direitos do consumidor o de receber informações claras e adequadas sobre os produtos ou serviços oferecidos. ${ }^{16}$ A lei de incorporações imobiliárias, apesar de ser bem mais antiga que o código, já específica com detalhes quais informações o incorporador deverá prestar ao adquirente do imóvel objeto da oferta.

Desta maneira, percebemos aqui um saudável diálogo das fontes normativas, uma vez que o código de defesa do consumidor possui uma previsão genérica de informação em todas as relações de consumo, enquanto a lei de incorporações é específica, atingindo apenas as relações que envolvam empreendimentos imobiliários.

\footnotetext{
12 PEREIRA, Caio Mario da Silva. Condomínio e incorporações. (11 a ed.) Rio de Janeiro: Forense, 2014, p. 207

13 BRASIL. Lei de Incorporações imobiliárias, lei 4.591 de 16 de dezembro de 1964, art. 32.

${ }^{14}$ Ibidem, art. $31 \S 2^{\circ}$.

${ }^{15}$ Ibidem, art. 31-D, IV.

16 BRASIL. Código de defesa do consumidor, lei 8.078, de 11 de setembro de 1990, art. $6^{\circ}$, III.
} 
Importante ressaltar que a lei de incorporações imobiliárias protege todos os adquirentes de imóveis objeto de incorporação, sejam eles enquadrados no conceito normativo de consumidor, do código de defesa, ou não. A lei de incorporações tutela, assim, até mesmo contratos efetuados entre um incorporador e uma pessoa jurídica de grande porte. O âmbito dessa lei no caso de incorporações é mais extenso que somente a proteção consumerista.

A lei de incorporações se encontra dentro do que se espera das modernas concepções de contrato, muito marcadas pela boa-fé e pela função social:

A lei especial que disciplina essa atividade estabelece objetivamente mecanismos destinados a assegurar a realização da função social do contrato e, nesse sentido, fixa limitações a que deve se submeter a autonomia do incorporador em todo o ciclo do contrato, desde a fase pré-contratual até a extinção do contrato, ditando os termos e a periodicidade em que o incorporador tem que cumprir o dever de informação, prevendo a criação de um patrimônio especial para cada incorporação, além de outros mecanismos visando a consecução da função social do contrato.

Essas e outras normas imperativas contidas na Lei das incorporações traduzem a noção contemporânea do contrato, em que se verifica a intervenção legislativa para assegurar o cumprimento da sua função social. Observe-se, por exemplo, que a exibição, no registro de imóveis das condições básicas da incorporação, assim como a informação periódica sobre a obra, correspondem aos deveres de lealdade, de confiança e de informação que corporificam o princípio da boa-fé e possibilitam ao pretendente a formação consciente da vontade de contratar, viabilizando, em consequência, o exercício efetivo da liberdade contratual. ${ }^{17}$

Não apenas a lei de incorporações imobiliárias e o código de defesa do consumidor seguem os princípios éticos modernos de lealdade, boa-fé e função social do contrato. Também o atual código civil brasileiro, de 2002, foi promulgado tendo por base tais princípios $^{18}$. Enquanto no passado existia alta liberdade de contratar, hoje tais princípios acabam por proteger os mais francos, em toada com a tendência do dirigismo contratual. ${ }^{19}$

Desta maneira, podemos perceber que a lei de incorporações imobiliárias possui um caráter marcante de proteção ao consumidor, em consonância com as tendências mais modernas do direito, apesar de ter sido promulgado nos idos dos anos 60. A lei de incorporações imobiliárias continua atual e plenamente aplicável na atualidade para as relações jurídicas envolvendo a compra e venda de imóveis projetados, ou seja, que não possuem ainda existência presente.

Pode-se então concluir que a lei de incorporações imobiliárias (aplicável a todos os adquirentes de imóveis objeto de incorporação) e o código de defesa do consumidor (aplicável

${ }^{17}$ CHALHUB, Melhim Namem. Incorporação imobiliária. (4a ed.) Rio de Janeiro: Forense, 2017, p.324.

${ }^{18}$ TEPEDINO, Gustavo; BARBOZA, Heloisa Helena; BODIN DE MORAES, Maria Celina de. Código civil interpretado - Conforme a Constituição da República, Vol. II. (2 ${ }^{\mathrm{a}}$ ed). Rio de Janeiro: Renovar, 2012, p. 14-15.

${ }^{19}$ GOMES, Orlando. Contratos. (16 ${ }^{\mathrm{a}}$ ed). Rio de Janeiro: Forense, 1995, p. 8. 
apenas quando pode-se enquadrar o comprador como consumidor) são complementares na proteção ao consumidor adquirente de um imóvel projetado.

1.2 A proteção do comprador de imóvel objeto de incorporação imobiliária por meio do Código de Defesa do Consumidor

Como visto, o contrato de compra e venda de unidades autônomas alvo de incorporação imobiliária, ou seja, unidades futuras, podem ser tidas como enquadradas dentro do âmbito do código de defesa do consumidor, caso o adquirente seja efetivamente um consumidor, ou seja, que irá utilizar do produto como destinatário final, o que não seria o caso de um investidor visando comprar uma unidade para especulação.

Desta maneira, muito bem diz Cláudia Lima Marques:

Quanto ao contrato de incorporação imobiliária, em que o incorporador faz
uma venda antecipada dos apartamentos, para arrecadar o capital necessário
para a construção do prédio, fácil caracterizar o incorporador como
fornecedor, vinculado por obrigação de dar (transferência definitiva) e de
fazer (construir). A caracterização do promitente comprador como
consumidor dependerá da destinação final do bem ou da aplicação de uma
norma extensiva, como a presente no art. 29 do CDC. Interessante notar que
qualquer dos participantes da cadeia de fornecimento é considerado
fornecedor e há solidariedade entre eles. Porém, em algumas circunstâncias,
o proprietário do imóvel mesmo que promitente vendedor, foi excluído da
cadeia de fornecimento pela jurisprudência, evitando a própria aplicação do
CDC, pois considerado mero contrato entre iguais. ${ }^{20}$

Desta maneira, como existe nesse tipo de contrato a aplicação do Código de Defesa do Consumidor, existe a previsão na lei da solidariedade entre todos os fornecedores da cadeia produtiva. No entanto, essa noção de solidariedade deve ser vista com bastante cuidado. Por evidente, podemos vislumbrar uma solidariedade entre o incorporador e o construtor, porém, por vezes, o vendedor do terreno não é um fornecedor, como no exemplo citado acima. Como nas incorporações imobiliárias existem feixes complexos de contratos, ou seja, contratos $\operatorname{coligados}^{21}$, não se pode interpretar o código de defesa do consumidor de forma literal e considerar que todos são necessariamente fornecedores.

A interpretação do código de defesa do consumidor deve ser efetuada levando-se em consideração a pluralidade de leis aplicáveis, em um diálogo das fontes entre o CDC, a lei de

\footnotetext{
20 MARQUES, Cláudia Lima. Contratos no código de defesa do consumidor - o novo regime das relações contratuais. ( $8^{\mathrm{a}}$ ed). São Paulo: Editora Revista dos Tribunais, 2016, p. 486-487.

21 DOS SANTOS, Flauzilino Araújo. Condomínio e incorporações no registro de imóveis. São Paulo: Editora Mirante, p. 290.
} 
incorporações imobiliárias, o código civil e outras leis $^{22}$, em especial aquelas que tratam de financiamento à habitação, uma vez que unidades novas são compradas por diversas vezes utilizando-se de financiamentos.

Vejam-se julgados sobre o tema:

Em que pese o contrato de incorporação ser regido pela Lei $n^{\circ} 4.591 / 64$, admite-se, outrossim, a incidência do Código de Defesa do Consumidor, devendo ser observados os princípios gerais do direito que buscam a justiça contratual, a equivalência das prestações e a boa-fé objetiva e vedam o locupletamento ilícito.(Brasil. Superior Tribunal de Justiça. Resp 747.768/PR, Rel. Ministro João Otávio de Noronha).

E também:

O contrato de incorporação, no que tem de específico, é regido pela Lei que lhe é própria (Lei $\mathrm{n}^{\circ}$ 4591/64), mas sobre ele também incide o Código de Defesa do Consumidor, que introduziu no sistema civil princípios gerais que realçam a justiça contratual, a equivalência das prestações e o princípio da boa-fé objetiva. (Brasil. Superior Tribunal de Justiça. REsp. n ${ }^{\circ}$ 95608634-SP, Relator Min. Ruy Rosado de Aguiar, in DJU 25/03/96, pag. 8586).

Essa aplicação que ocorre de uma lei por vezes, e por vezes de outra, gera, obviamente, uma insegurança jurídica para os adquirentes e os vendedores. Essa insegurança aumenta os custos dos empreendimentos e todo esse complexo legal possui um efeito nefasto exatamente sobre quem quer proteger: o adquirente. Isso porque ao final, os custos legais irão incidir sobre o preço que este pagará pela unidade imobiliária que ele deseja adquirir. ${ }^{23}$

Portanto, é admitido a aplicação do código de defesa do consumidor, porém, com a observação das peculiaridades aplicáveis às incorporações imobiliárias:

A rigor, as normas que dispõem sobre a tipificação e a funcionalidade desses tipos contratuais devem ser tomadas como balizamento da interpretação, não só porque elas prevalecem sobre as normas gerais instituídas pelo CDC, naquilo que tem de específico, pois é nelas que se encontra a definição da estrutura e função desses contratos, mas, também, porque a lei das incorporações consubstancia um sistema de proteção do adquirente mais fraco, sistema esse dotado de efetividade específica, porque instituído em estrita conformidade com a estrutura e a função dos contratos em questão.

Disso é exemplo o art. 50 da lei 10.931/2004, que trata especificamente das ações revisionais de obrigação de pagamento parcelado do preço de aquisição do imóvel. /caso, por exemplo, o adquirente alegue que foi fixada no contrato taxa de juros acima do limite legal, incide o art. 51 do CDC. Entretanto, o art. 50 e seus parágrafos da lei 10.931/2004 regulamentam a

\footnotetext{
22 MARQUES, Cláudia Lima. Contratos no código de defesa do consumidor - o novo regime das relações contratuais. ( $8^{\mathrm{a}}$ ed). São Paulo: Editora Revista dos Tribunais, 2016, p. 488.

23 Sobre a influência do direito (especialmente das intervenções governamentais no direito) e seu custo social e econômico, recomendamos a obra clássica sobre o tema: COASE, Ronald. A firma, o mercado e o direito. ( $\left(2^{\mathrm{a}}\right.$ ed) Rio de Janeiro: Forense, 2017.
} 
matéria de maneira compatível com a situação, ao assegurar ao devedor o direito de bloquear o pagamento da parcela por ele definida por controvertida, determinando seu depósito à disposição do juízo e admitindo, a critério do juiz, a suspensão de sua exigibilidade; de outra parte esses mesmos dispositivos determinam a continuação do pagamento da parcela definida pelo devedor como incontroversa, com o que se evita a interrupção total do fluxo financeiro do contrato. ${ }^{24}$

Desta maneira, deve o operador do direito interpretar a norma de maneira a extrair da mesma quais são as regras aplicáveis para o caso específico. Afinal, de um lado temos norma especial (a lei de incorporação imobiliária) e de outro temos norma posterior (o código de defesa do consumidor). Esse conflito de leis possuí solução. Se trata apenas de uma antinomia aparente. ${ }^{25}$ Ou seja, onde houver norma específica, devemos aplicar a lei de incorporações imobiliárias. Caso essa não exista, será aplicado o código de defesa do consumidor.

A interpretação (ou exegese, como preferem alguns) deve se utilizar, além dos critérios para a resolução de antinomias, também a aplicação da forma clássica de resolução de conflitos, ou seja, a teoria da subsunção jurídica do fato à norma e a aplicação dos cânones tradicionais de interpretação do direito, como a análise gramatical, a lógica, a histórica e a sistemática. ${ }^{26}$

Apesar disso, existem divergências na aplicação do direito em diversas situações envolvendo contratos relativos a incorporações imobiliárias. Uma divergência mais latente é a respeito da aplicação ou não do artigo 20, II do código de defesa do consumidor às incorporações imobiliárias. Tal artigo exige a restituição imediata ao consumidor das quantias por ele pagas no caso de desfazimento do contrato. ${ }^{27}$

Ocorre que se esse artigo fosse aplicado integralmente às incorporações imobiliárias, haveria um prejuízo muito grande à continuidade da própria incorporação imobiliária, uma vez que as quantias pagas no contrato de incorporação são “imediatamente convertidas em pedra e cal, sendo materialmente impossível sua reconversão imediata em dinheiro, para atender a pretensão de restituição do desistente, como previsto no inciso II do art. 20 do CDC. $" 28$

A devolução imediata do valor iria aplicar em coisas diferentes a mesma lei. É evidente, e até mesmo óbvio que não se pode tratar da mesma forma a venda de bens fungíveis para consumo e a venda de imóveis em empreendimentos. Ambas as atividades devem ser

\footnotetext{
${ }^{24}$ CHALHUB, Melhim Namem. Incorporação imobiliária. (4a ed.) Rio de Janeiro: Forense, 2017, p. 339.

25 V. KÜMPEL, Vitor Frederico. Introdução ao estudo do direito. São Paulo: Método, 2009.

26 SAVIGNY, Friedrich Karl Von. Sistema Del derecho romano actual. Granada: Editorial Comares, 2005, p. 96.

27 BRASIL. Código de defesa do consumidor, lei 8.078, de 11 de setembro de 1990, art. 20, II.

${ }^{28}$ CHALHUB, Melhim Namem. Incorporação imobiliária. (4ª ed.) Rio de Janeiro: Forense, 2017, p. 344.
} 
separadas pelo direito, até por bem dos compradores. Não por certo do comprador que quer ter seu contrato rescindido e receber de volta o valor pago, mas sim de toda comunidade de adquirentes. Caso seja sempre restituído o valor pago imediatamente e de forma integral, a continuidade da obra ficaria comprometida, uma vez que o fluxo de caixa do construtor muitas vezes não seria suficiente para pagar os valores do adquirente retirante e, ao mesmo tempo, continuar com a obra.

O código de defesa do consumidor parece tratar muitas vezes o empresário como tendo quantidades infindáveis de dinheiro e uma margem de lucro absurda, coisa que não ocorre na realidade.

Em uma economia capitalista, de mercado, as margens de lucro são sempre jogadas para baixo por conta da competição. Apenas em ramos que tenham um monopólio ou um oligopólio as margens são altas. No entanto, em incorporações imobiliárias não há barreira para entrada de novos competidores, forçando os preços para baixo. Em direito, muitas vezes não é feita uma análise econômica dos impactos que a legislação proposta terá, o que acaba por gerar distorções que geram custos que são repassados ao consumidor. ${ }^{29}$

\subsection{Multa contratual no caso de atraso na conclusão da obra}

Tema de grande relevância para o estudo da aplicação da lei consumerista às incorporações imobiliárias é a aplicação da multa contratual nos casos de atraso na conclusão e por consequência, na entrega da obra. Isso porque o atraso na entrega da obra gera gastos ao consumidor, que muitas vezes tem que pagar um aluguel pois não pode ainda habitar o imóvel adquirido.

O instrumento de promessa de compra e venda pode implicar na aplicação de multa a favor do adquirente, suportada pelo vendedor, quando o prazo para conclusão das obras for extrapolado.

A jurisprudência pátria se posiciona em relação à entrega tardia da obra e a incidência de multa:

AÇÃO DE INDENIZAÇÃO. COMPRA E VENDA DE IMÓVEL. ATRASO NA ENTREGA. MORA CARACTERIZADA. A expedição do habite-se não equivale a efetiva entrega das chaves, que deve ser considerada como termo final da mora das rés - É cabível a condenação por lucros cessantes no caso de descumprimento do prazo para entrega do imóvel - Prejuízo in re ipsa, que se caracteriza pela

${ }^{29}$ Sobre a análise econômica do direito, vide o clássico livro a esse respeito: COASE, Ronald. A firma, o mercado e o direito. ( $2^{\mathrm{a}}$ ed) Rio de Janeiro: Forense, 2017. 
não fruição do bem - Precedentes do STJ - Verba fixada em 0,5\% do valor atualizado do contrato, de acordo com os parâmetros da Corte Multa contratual devida em razão do comprovado atraso na entrega do imóvel - Existência de previsão de multa para a compradora - Cabível a aplicação por analogia - Diferenciação entre lucros cessantes e multa moratória - Dano Moral - Inocorrência - Descumprimento contratual que se qualifica como aborrecimento, mas que não atingiu a honra ou a imagem do autor - Recurso do autor parcialmente provido e desprovido os das rés (BRASIL. TJSP - APL 1056476 47.2014.8.26.0100 - Órgão Julgador: $7^{\mathrm{a}}$ Câmara de Direito Privado Publicação: 16/10/2015 - Julgamento: 16/10/2015 - Relator: Miguel Brandi).

O Código Civil dispõe a respeito da multa por atraso no cumprimento da prestação em seus artigos 408 e 409. Já a cláusula penal é obrigação acessória com previsão no contrato realizado entre as partes, portanto, igualmente, precisa ser cumprida.

Art. 408. Incorre de pleno direito o devedor na cláusula penal, desde que, culposamente, deixe de cumprir a obrigação ou se constitua em mora.

Art. 409. A cláusula penal estipulada conjuntamente com a obrigação, ou em ato posterior, pode referir-se à inexecução completa da obrigação, à de alguma cláusula especial ou simplesmente à mora. ${ }^{30}$

Quando provada a negligência do vendedor que, por seus atos e responsabilidade, venha provocar ofensa à moral do comprador trazendo transtornos em sua vida privada, pode ele buscar indenização, assim como o ressarcimento material, por conta do transtorno e da insatisfação que o episódio traz ao adquirente.

Tais artigos do código civil, quando da ocorrência da relação de consumo, deverão ser lidos à luz dos princípios do código de defesa do consumidor. Assim, mais uma vez temos que recorrer ao diálogo das fontes.

1.4 Rescisão contatual de contrato de compra e venda de unidades objeto de incorporação no âmbito do código de defesa do consumidor

A aquisição de imóveis na planta tem suas condições acordada no contrato de promessa de compra e venda de imóvel. Nesse instrumento, as partes definem as regras que irão vigorar para: "pagamento, data de entrega do imóvel e diversas outras cláusulas necessárias ao negócio”. 31

${ }^{30}$ BRASIL. Código Civil, lei 10.406, de 10 de janeiro de 2002, arts. 408 e 409.

31 MELO, Jamil Nadaf de. Rescisão de contrato de imóvel comprado na planta por culpa do comprador, qual o limite da multa aplicada? (2017). Disponível em 
Em geral, nesses contratos de aquisição de imóveis na planta firmados com as construtoras é realizado o pagamento de uma entrada na assinatura do mesmo, com parcelas mensais no período de construção do empreendimento e a quitação total do saldo devedor na entrega do imóvel.

Durante a construção, alguns compradores não conseguem o financiamento que pretendem, e assim, se arrependem da realização do negócio ou não têm condições financeiras para honrar com o compromisso assumido.

Sendo assim, há necessidade de rescisão do contrato, porém, existem contratos omissos com relação à multa que estará obrigado o comprador/consumidor que desiste do negócio, ou, quando prevista, a multa é abusiva.

Então, quando a quebra de contrato parte do comprador/consumidor ou se dá pela falta de pagamento dos valores acordados, sem que haja culpa da construtora/incorporadora, o usual no mercado é que o vendedor retome seus direitos sobre a unidade imobiliária. Assim como, deve devolver os valores pagos pelo comprador/consumidor, apenas retenha um percentual desse valor para efeito de multa pela quebra do pacto.

Quanto ao limite dessa multa o Superior Tribunal de Justiça já decidiu quanto à questão em vários julgados pacificando o entendimento de que o vendedor tem o direito de reter de $10 \%$ a $25 \%$ dos valores pagos pelo adquirente.

Mesmo quando a cláusula contratual tenha previsão de multa no percentual de $50 \%$, o comprador/consumidor pode se valer da via judicial para requere a readequação da no caso concreto. Uma vez que há vedação do artigo 51, IV do Código de Defesa do Consumidor quanto à abusividade no cumprimento das obrigações que deixem o consumidor em situação de desvantagem exagerada.

Art. 51. São nulas de pleno direito, entre outras, as cláusulas contratuais relativas ao fornecimento de produtos e serviços que:

(...)

IV - estabeleçam obrigações consideradas iníquas, abusivas, que coloquem o consumidor em desvantagem exagerada, ou sejam incompatíveis com a boa-fé ou a equidade;

Apesar do Superior Tribunal de Justiça ter fixado o limite mínimo de $10 \%$ e o máximo de $25 \%$ estes devem ser analisados conforme o caso concreto, pois depende das condições específicas em que o negócio foi pactuado que, associado ao princípio

<https://melojamil.jusbrasil.com.br/artigos/395848929/rescisao-de-contrato-de-imovel-comprado-naplanta-por-culpa-do-comprador-qual-o-limite-da-multa-aplicada. Acesso em 07 maio 2018. 
da razoabilidade, deve reembolsar o vendedor pelas despesas administrativas desembolsadas com o negócio. Então, conforme explica Jamil Nadaf de Melo:

(...) não basta o vendedor fixar em contrato o máximo permitido pelo Tribunal Superior e o caso concreto demonstrar que a resolução do contrato trouxe poucos prejuízos à empresa. Caso o comprador/consumidor ingresse em juízo, poderá reduzir a multa para um valor mais compatível com a situação enfrentada. ${ }^{32}$

Valendo observar que no entendimento do Superior Tribunal de Justiça os valores precisam ser devolvidos ao comprador/consumidor de forma imediata e à vista, considerando abusiva a devolução parcelada ou a devolução somente apenas na conclusão da obra.

Desta forma, é preciso que o comprador/consumidor, ao assinar um contrato de promessa de compra e venda de imóvel, exija a fixação da multa, que não deve ser abusiva no caso de rescisão do contrato por parte do comprador/consumidor.

A desistência da compra do imóvel na planta é um dos principais motivos da incidência de processos contra as construtoras no Brasil. O direito de distrato de imóvel tem previsão na Lei $n^{\circ} 4.591 / 64$, assim como, a devolução do valor pago está consolidada na jurisprudência pátria. Então, a construtora deve ressarcir o cliente com os valores devidamente corrigidos e numa única parcela, independentemente do mutuário estar inadimplente ou não.

Nos dias atuais são muitas as razões que fazem com que algumas pessoas não consigam cumprir seus compromissos financeiros. Por outro lado, devido a esse momento de crise econômica que o país atravessa inúmeras construtoras também não estão cumprindo a data da entrega de seus imóveis ou até mesmo não os estão entregando.

Outro motivo que provoca a inadimplência do comprador é, além da perda do emprego e, por consequência, de renda, está nos juros abusivos cobrados pelos bancos para concessão de empréstimos, fazendo com que as pessoas evitem recorrer a empréstimos bancários para quitarem suas parcelas junto às construtoras. Porém, é simples resolver a questão com o distrato.

O distrato é um mecanismo jurídico que permite uma pessoa física ou jurídica interromper em definitivo um contrato anteriormente assumido que não foi cumprido

32 MELO, Jamil Nadaf de. Rescisão de contrato de imóvel comprado na planta por culpa do comprador, qual o limite da multa aplicada? (2017). Disponível em $<$ https://melojamil.jusbrasil.com.br/artigos/395848929/rescisao-de-contrato-de-imovel-comprado-naplanta-por-culpa-do-comprador-qual-o-limite-da-multa-aplicada. Acesso em 07 maio 2018. 
na íntegra. Sendo que tal procedimento tanto pode ocorrer com o consentimento entre ambas as partes como através de notificação de uma das partes à outra.

A compra de imóvel na planta é uma operação que implica em riscos para todas as partes, principalmente para o comprador que paga antecipadamente e fica por longo tempo sem receber o imóvel, ou seja, nesse período é um bem intangível, pois existe somente um compromisso de entrega futura.

Já o vendedor-construtor passa por riscos que devem ser calculados, mensurados e incluídos no preço do imóvel e algumas eventuais perdas no curto prazo, devido à crise que atravessa o país, mas que, certamente já foram compensadas por altos lucros em períodos anteriores quando os imóveis tiveram, em alguns casos, $300 \%$ de aumento.

A partir da queda das taxas de juros e da consequente retomada da economia, as construtoras com boa estrutura conseguirão se manter no mercado e aquelas que não possuem estrutura e falta de qualidade na gestão obviamente estarão condenadas ao desaparecimento, sendo este mais um ciclo da economia que implica no risco do negócio.

Não há dúvidas de que a judicialização do tema é consequência muitas vezes da falta de bom senso das construtoras, as quais visam minimizar os efeitos da crise em seu negócio por meio de propostas impraticáveis aos consumidores, que vão desde permutas para imóveis que não possuem liquidez até a oferta de devolução de valores irrisórios comparada ao valor que foi pago.

No caso de propostas das incorporadoras que não tenham amparo na realidade, estas afrontam o disposto no artigo 53 do CDC, o qual determina a nulidade das cláusulas que preveem a perda das parcelas já pagas. ${ }^{33}$

Conforme as observações feitas por Jose Maria Franco de Godoi Neto:

Os consumidores, já fragilizados pela situação de não aprovação de financiamento ou desemprego acabam aceitando valores irrisórios em virtude da dificuldade financeira, pois alternativa não lhe restam. (...) Não se pode cogitar que as construtoras em caso de distrato fiquem com o imóvel para revenda e com quase a totalidade dos recursos financeiros do consumidor, se enriquecendo ilicitamente. ${ }^{34}$

\footnotetext{
33 BRASIL. Código de defesa do consumidor, lei 8.078, de 11 de setembro de 1990, art. 51.

34 GODOI NETO, José Maria Franco de. O distrato de imóvel na planta: controvérsias e reflezxões (2017). Disponível em <http://www.migalhas.com.br/dePeso/16,MI254824,21048O+distrato+de+imovel+na+planta+controversias+e+reflexoes. Acesso em 17 maio 2018.
} 
O distrato ocorre a partir de três situações: $1^{\text {a }} \mathrm{O}$ comprador que, por impedimentos alheios a sua vontade, fica sem condições financeiras de adimplir o contrato; $2^{\mathrm{a}} \mathrm{O}$ comprador-investidor que, mesmo sendo pontual durante anos, verifica que o valor do imóvel à vista fica mais barato que o saldo remanescente com a construtora; $3^{\mathrm{a}} \mathrm{O}$ comprador resolve rescindir o contrato por culpa exclusiva do vendedor que atrasa a entrega do imóvel.

Os parâmetros do distrato já foram determinados pelo Judiciário e estão fundamentados em inúmeras decisões. As regras consistem em por exemplo, devolução total dos valores no caso de rescisão por culpa da incorporadora, ou parcial, no caso de rescisão por culpa do comprador. Assim se manifestou o Tribunal de Justiça do Distrito Federal e Territórios TJ-DF:

APELAÇÃO CÍVEL. PROMESSA DE COMPRA E VENDA. IMÓVEL NA PLANTA. DISTRATO. DEVOLUÇÃO DAS PARCELAS PAGAS. CLÁUSULA PENAL COMPENSATÓRIA. REDUÇÃO. ARRAS CONFIRMATÓRIAS. RETENÇÃO. IMPOSSIBILIDADE. 1. Embora seja lícita a fixação de cláusula penal compensatória para os casos em que haja o desfazimento da promessa de compra e venda por iniciativa do promissário comprador, o valor da referida penalidade deve atender aos postulados da razoabilidade e a boa-fé. 2. A inteligência majoritária deste Tribunal é a de que, nas hipóteses em que a cláusula penal seja fixada em montante excessivo, afigura-se razoável a redução do importe suscetível de ser retido pela promitente vendedora para o percentual de $10 \%$ (dez por cento) sobre o valor das parcelas pagas. 3. Em regra, as arras possuem natureza confirmatória, consistindo em princípio de pagamento, com a finalidade de confirmar o negócio jurídico. Como foi ultrapassada a fase das tratativas, mediante a efetiva celebração da promessa de compra e venda, as arras passaram a incorporar o montante de quitação do saldo devedor, nos termos do art. 417 do Código Civil, sem que se cogite de sua retenção a qualquer título na hipótese de resilição bilateral. 4. Apelação não provida (BRASIL. Tribunal de Justiça do Distrito Federal e Territórios TJ-DF - Apelação Cível: Apc 20140310108623 - Órgão Julgador: $2^{\mathrm{a}}$ Turma Cível - Publicação: 18/09/2015 - Julgamento: 09/09/2015 - Relator: J. J. COSTA CARVALHO).

Não apenas os tribunais estaduais, mas os tribunais superiores também se manifestaram a respeito do tema. Os repetidos julgamentos relativos a matéria levaram o STJ a edição do enunciado de número 543, que possui o seguinte texto:

Súmula 543: Na hipótese de resolução de contrato de promessa de compra e venda de imóvel submetido ao Código de Defesa do Consumidor, deve ocorrer a imediata restituição das parcelas pagas pelo promitente comprador - integralmente, em caso 
de culpa exclusiva do promitente vendedor/construtor, ou parcialmente, caso tenha sido o comprador quem deu causa ao desfazimento. ${ }^{35}$

O Superior Tribunal de Justiça tem entendido que os valores devem ser devolvidos de uma só vez (o que prejudica o fluxo financeiro da incorporadora), porém, com direito a retenção de valores que vão de 10 a $25 \%$ no caso de desfazimento do negócio culpa do comprador. $^{36}$ A devolução deverá ser feita de forma integral, no caso de culpa do incorporador.

Seria melhor, e mais adequado ao modelo de negócio em análise que a devolução fosse feita de maneira escalonada, de forma a não prejudicar o fluxo de caixa do empreendimento. Mesmo que a devolução fosse efetuada de forma sempre integral ao comprador, isso não prejudicaria tanto o incorporador, pois após o empreendimento terminado, a unidade objeto de devolução teria se valorizado sobremaneira.

\section{Conclusão}

Por todo exposto, concluímos primeiramente pela aplicabilidade do código de defesa do consumidor às incorporações imobiliárias, quando o adquirente se enquadra na definição legal de consumidor fornecida pela legislação consumerista.

No entanto, essa aplicabilidade deve ser vista por meio da aplicação de um saudável diálogo das fontes normativas, de maneira que o código de defesa do consumidor é aplicável quando não exista regulamentação específica dada pela lei de incorporações imobiliárias, que foi embebida dos mesmos princípios protetivos que o código consumerista.

Além disso, cabe ainda a aplicação do código civil brasileiro, datado de 2002, que, diferentemente do código anterior, possui uma grande influência da legislação de cunho social.

Percebemos ainda que a legislação de proteção ao consumidor adquirente de imóveis objeto de incorporações imobiliárias é suficiente e equilibrada. No entanto, percebemos que a multiplicidade de fontes normativas gera insegurança jurídica, bem como lacunas na lei, que são preenchidas por decisões judiciais, que muitas vezes não conseguem trazer uma perspectiva satisfatória em termos de previsibilidade.

Desta maneira, concluímos que o ideal em termos de legislação protetiva ao compradorconsumidor de incorporações imobiliárias seria a edição de uma lei específica, que

35 BRASIL. Superior Tribunal de Justiça. Súmula 543, SEGUNDA SEÇÃO, julgado em 26/08/2015, DJe 31/08/2015

${ }^{36}$ BRASIL. Superior Tribunal de Justiça. AgInt no REsp 1361921/MG, Rel. Ministro Marco Aurélio Bellizze, $3^{\mathrm{a}}$ Turma, julgado em 23/6/2016, DJe 1\%/7/2016. 
regulamentasse de maneira geral a matéria, afastando a aplicabilidade dos demais diplomas legais e, ao mesmo tempo, dando a segurança jurídica necessária a todos os envolvidos no contrato.

\section{REFERENCIAS}

AGHIARIAN, Hércules. Curso de Direito imobiliário. (9a ed). Rio de Janeiro: Lumen Juris, 2010.

ASSIS, Araken de. Fraude contra execução no registro de imóveis. In: DIP, Ricardo (coord.). Direito Registral e o novo Código de processo civil. Rio de Janeiro: Forense, 2016.

ÁVILA, Humberto. Teoria da Segurança Jurídica. (3 ${ }^{\mathrm{a}}$ ed.) São Paulo: Malheiros Editores, 2014.

AVVAD, Pedro Elias. Direito Imobiliário - teoria geral e negócios imobiliários. ( $3^{\mathrm{a}}$ ed.) Rio de Janeiro: Forense, 2012.

BELO, Emília; ACCIOLY, Rafael. Lei 13.465/2017 inova e possibilita criação de condomínio de lotes. Disponível em:<http://iregistradores.org.br/lei-13-4652017-inova-epossibilita-criacao-de-condominio-de-lotes/. Acesso em 06 de abril de 2018

BRASIL. Constituição da República Federativa do Brasil. 1988.

BRASIL. Código de defesa do consumidor, lei 8.078, de 11 de setembro de 1990

BRASIL. Lei de Incorporações imobiliárias, lei 4.591 de 16 de dezembro de 1964.

BRASIL. Código Civil, lei 10.406, de 10 de janeiro de 2002.

BRASIL. TJSP - APL 1056476 -47.2014.8.26.0100 - Órgão Julgador: 7ª Câmara de Direito Privado - Publicação: 16/10/2015 - Julgamento: 16/10/2015 - Relator: Miguel Brand

BRASIL. Tribunal de Justiça do Distrito Federal e Territórios TJ-DF - Apelação Cível: Apc 20140310108623 - Órgão Julgador: 2a Turma Cível - Publicação: 18/09/2015 - Julgamento: 09/09/2015 - Relator: J. J. COSTA CARVALHO.

BRASIL. Superior Tribunal de Justiça. Súmula 543, SEGUNDA SEÇÃO, julgado em 26/08/2015, DJe 31/08/2015

BRASIL. Superior Tribunal de Justiça. AgInt no REsp 1361921/MG, Rel. Ministro Marco Aurélio Bellizze, $3^{\text {a }}$ Turma, julgado em 23/6/2016, DJe 1\%/7/2016.

BULGARELLI, Waldirio. Questões Contratuais no código de defesa do consumidor. São Paulo: Editora Atlas, 1993.

BULOS, Uadi Lammêgo. Curso de Direito Constitucional. (10 ed). São Paulo: Saraiva, 2017.

CAnOtilho, J. J. Gomes. Direito Constitucional e Teoria da Constituição. ( $7^{\mathrm{a}}$ ed). Coimbra: Edições Almedina S.A, 2003.

CAVAliERI FILHO, Sergio. Programa de direito do consumidor. ( $1^{\text {a }}$ ed.) São Paulo: Editora Atlas, 2009.

CHALHUB, Melhim Namem. Alienação fiduciária, incorporação imobiliária e mercado de capitais - estudos e pareceres. Rio de Janeiro: Renovar, 2012. 
CHALHUB, Melhim Namem. Incorporação imobiliária. (4a ed.) Rio de Janeiro: Forense, 2017.

CHALHUB, Melhim Namem. Condomínio de lotes de terreno urbano in Revista de Direito Imobiliário, ano 31, V. 67, jul-dez/2009.

CHALHUB, Melhim Namen. A afetação do acervo em incorporações imobiliárias. In: TUTIKIAN, Cláudia Fonseca (org). Novo direito Imobiliário e Registral. (2 ${ }^{\mathrm{a}}$ Ed) São Paulo: Quartier Latin, 2010

CHALHUB, Melhim Namem. Alienação Fiduciária: Negócio fiduciário. (5 ${ }^{\mathrm{a}}$ ed.) Rio de Janeiro: Forense, 2017.

COELHO, Fábio Ulhoa. Curso de direito comercial, vol. 3. (11 ${ }^{\mathrm{a}}$ ed). São Paulo: Editora Saraiva, 2010.

COASE, Ronald. A firma, o mercado e o direito. (2 ${ }^{\mathrm{a}}$ ed) Rio de Janeiro: Forense, 2017.

DOS SANTOS, Flauzilino Araújo. Condomínio e incorporações no registro de imóveis. São Paulo: Editora Mirante

FABIAN, Cristoph. Fidúcia - negócios fiduciários e relações externas. Porto alegre: Sergio Antonio Fabris Editor, 2007.

FIORANELLI, Ademar. Direito registral imobiliário. Porto Alegre: Sergio Antônio Fabris Editor, 2011.

KÜMPEL, Vitor Frederico. Introdução ao estudo do direito. São Paulo: Método, 2009.

GOMES, Orlando. Contratos. (16 ${ }^{\mathrm{a}}$ ed). Rio de Janeiro: Forense, 1995.

GODOI NETO, José Maria Franco de. O distrato de imóvel na planta: controvérsias e reflezxões (2017). Disponível em <http://www.migalhas.com.br/dePeso/16,MI25482 4,210480+distrato+de+imovel+na+planta+controversias+e+reflexoes. Acesso em 17 maio 2018.

RADBRUCH, Gustav. Introdução à ciência do direito. ( $2^{\mathrm{a}}$ ed). São Paulo: Martins Fontes, 2010

HOPPE, Hans Herman. Democracia: O Deus que falhou. São Paulo: Instituto Ludwig Von Mises Brasil, 2014.

JÚNIOR, Antônio dos Reis. A promessa de compra e venda de imóveis: Os efeitos do inadimplemento em perspectiva civil-constitucional. São Paulo: Almedina Brasil, 2018.

MARTINS, Raphael Manhães. A propriedade fiduciária no direito brasileiro - uma proposta para a construção dogmática do modelo. Revista da EMERJ, Rio de Janeiro, v. 13, n. 51, 2010, p. 129-147.

MARQUES, Cláudia Lima. Contratos no código de defesa do consumidor - o novo regime das relações contratuais. ( $8^{\mathrm{a}}$ ed). São Paulo: Editora Revista dos Tribunais, 2016.

MATTOS, Aldo Dórea. Patrimônio de afetação na Incorporação imobiliária - mais proteção para o adquirente. São Paulo: Pini, 2011.

MELO, Jamil Nadaf de. Rescisão de contrato de imóvel comprado na planta por culpa do comprador, qual o limite da multa aplicada? (2017). Disponível em $<$ https://melojamil.jusbrasil.com.br/artigos/395848929/rescisao-de-contrato-deimovel-comprado-na-planta-por-culpa-do-comprador-qual-o-limite-da-multa-aplicada. Acesso em 07 maio 2018. 
MORAES, Alexandre de. Direito Constitucional. (33ª ed). São Paulo: Atlas, 2017.

PEREIRA, Caio Mario da Silva. Condomínio e incorporações. (11 ${ }^{\mathrm{a}}$ ed.) Rio de Janeiro: Forense, 2014.

PONTES DE MIRANDA, Francisco Cavalcanti. Tratado de direito privado. Parte geral. Tomo III:Negócios jurídicos. Representação. Conteúdo. Forma. Prova. Rio de Janeiro: Editor Borsoi, 1954.

PORTUGAL. Constituição da República Portuguesa. 1976.

RIZZARDO, Arnaldo. Condomínio edilício e incorporação imobiliária. (5 $\left.5^{\mathrm{a}} \mathrm{ed}\right)$ Rio de Janeiro: Forense.

ROSENVALD, Nelson; DE FARIAS, Cristiano Chaves. Direitos Reais. Rio de Janeiro:Lúmen Júris, 2006

SARMENTO FILHO, Eduardo Sócrates Castanheira. Loteamento fechado ou condomínio de fato. $\left(1^{a}\right.$ ed) Curitiba: Juruá Editora, 2007.

SARMENTO FILHO, Eduardo Sócrates Castanheira. Direito Registral Imobiliário, Vol. I: Teoria Geral. Curitiba: Juruá Editora, 2018.

SARMENTO FILHO, Eduardo Sócrates Castanheira. Direito Registral Imobiliário, Vol II: Sujeitos, imóveis e direitos inscritíveis. Curitiba: Juruá Editora, 2018.

SAVIGNY, Friedrich Karl Von. Sistema Del derecho romano actual. Granada: Editorial Comares, 2005

Superior Tribunal de Justiça. Resp 747.768/PR, Rel. Ministro João Otávio de Noronha

Superior Tribunal de Justiça. REsp. n 95608634-SP, Relator Min. Ruy Rosado de Aguiar, in DJU 25/03/96, pag. 8586

TEPEDINO, Gustavo; BARBOZA, Heloisa Helena; BODIN DE MORAES, Maria Celina de. Código civil interpretado - Conforme a Constituição da República, Vol. II. (2 $2^{\mathrm{a}}$ ed). Rio de Janeiro: Renovar, 2012.

VENOSA, Silvio de Salvo. Direito civil: Teoria Geral das obrigações e Teoria geral dos contratos. (4 ${ }^{a}$ ed) São Paulo: Atlas, 2004.

VENOSA, Silvio de Salvo. Direito civil: contratos em espécie. (10 ed) São Paulo: Atlas, 2010.

VENOSA, Silvio de Salvo. Direito civil: Direito das sucessões. (6 ${ }^{\mathrm{a}}$ ed) São Paulo: Atlas, 2006. 